\title{
Distribution of structural funds: equity, efficiency and public procurement (Czech Republic)
}

\author{
Oldřich Hájek \\ Tomas Bata University in Zlin \\ Czech Republic \\ hajek@fame.utb.cz \\ Jiří Novosák \\ Tomas Bata University in Zlin \\ Czech Republic \\ novosak@fame.utb.cz \\ Jana Nekolová \\ Tomas Bata University in Zlin \\ Czech Republic \\ nekolova@fame.utb.cz \\ Lenka Smékalová \\ Tomas Bata University in Zlin \\ Czech Republic \\ smekalova@fame.utb.cz
}

Abstract. This article deals with structural funds allocation for projects realized by Czech regional and local authorities in the programming period 2007-2013. Geographical distribution of structural funds in the context of the equity and efficiency goals is mapped. Two research questions are formulated in this regard. The first research question concerns the position of lagging regions in structural funds allocation. The second research question maps spatial spillovers of public procurement contracts supported by structural funds. The findings point at a rather disadvantaged position of lagging regions in structural funds allocation. This position is further worsened by spatial spillovers of public procurement contracts. Thus, spatial coherence between the EU and Czech regional policies is questioned.

Keywords: structural funds, public procurement, regional disparities, Czech Republic

JEL Classification: R12, O18, R58, O22 


\section{INTRODUCTION}

Public finance is a considerable topic of economic research. One strand of research deals with the relationship between public finance and economic growth. In this regard, the position of public finance in economic growth theories (see, e.g., Auteri and Costantini, 2004; Barro and Sala-i-Martin, 1992) and the impact of public finance on economic growth (see, e.g., Afonso and Furceri, 2010) are discussed. Fiscal decentralization adds the spatial dimension into the discussion (see, e.g., Rodríguez-Pose and Ezcurra, 2011; Davoodi and Zou, 1998).

The other strand of research is positioned in the interplay between the equity and efficiency goals of public finance allocation. From the spatial perspective, the equity goal is connected with public finance allocation in lagging regions, while the efficiency goal with public finance allocation in main growth regions (see, e.g., Morgenroth, 2010). Note an increasing political emphasis on the spatial allocation of public funding. This is especially true for the EU territory because territorial cohesion was inserted into the Lisbon Treaty alongside economic and social cohesion (see, e.g., Camagni, 2009; Golobic and Marot, 2011; Novosák et al., 2013). It is highly desirable, therefore, to map the geographical pattern of public finance allocation.

Despite its importance, mapping of geographical distribution of public finance has several limitations. Firstly, Blažek and Macešková (2010), Morgenroth (2010), Cabras (2011), Heald and Short (2002) point out the lack of spatially disaggregated data. Secondly, Blažek and Macešková (2010), Dall'erba and Le Gallo (2008) speak about different geographical distribution of public finance when considering real allocation on one hand and beneficiaries' location (headquarter) on the other. Thirdly, Heald and Short (2002) note limited knowledge about spatial spillovers of public funds. Thus, for example, geographical distribution of public finance may be changed by the allocation of public procurement contracts (see, e.g., Cabras, 2011; Peck and Cabras, 2011). Altogether, geographical distribution of public finance remains often unknown.

This paper is embedded in the aforementioned theoretical framework, including the three research limitations. The goal is to map geographical distribution of EU structural funds (hereafter referred to as $\mathrm{SFs}$ ) in the context of the equity and efficiency goals. Moreover, the role of public procurement contracts is evaluated. The focus of this paper is on projects supported by SFs in the programming period 2007-2013 (excluding the European territorial cooperation goal) and realized by regional and local authorities in the Czech Republic. Note that SFs were a key instrument of, and regional and local authorities were important stakeholders of Czech regional development strategies in this period (see, e.g., Wokoun, 2007). The main results of this paper do not indicate higher SFs allocation in lagging regions (see, e.g., Hájek et al., 2012; Hájek, et al., 2014 for similar conclusions). The position of lagging regions was, in addition, worsened by the allocation of public procurement contracts.

The article is structured as follows. The next section summarizes the main findings from literature review. In section 2, the research methodology is introduced. The third and the fourth sections discuss the main findings from the research. The last section concludes.

\section{LITERATURE REVIEW}

The research on geographical pattern of public finance is closely related to fiscal transfers. The essence of fiscal transfers is to redistribute public finance from relatively "rich" to relatively "poor" territorial units. To create and secure uniform living standards through the territory is the main goal of fiscal transfers in Germany, for example (see, e.g., Jüßen, 2006; Hepp and von Hagen, 2011). The arguments of economic inefficiency and political instability arising from large territorial disparities are used to substantiate fiscal 
transfers (see, e.g., Boldrin and Canova, 2001; Heidenreich and Wunder, 2008). However, real allocation of public finance may be different from the "rich-poor" gradient. At least two explanations may be given:

- Firstly, Hepp and von Hagen (2011), Schraff (2014), Dellmuth and Stoffel (2012) point out asymmetries of negotiating power of particular territorial units due to, among others, their level of economic development and number of inhabitants. Lagging regions are often disadvantaged in this regard (see, e.g., Rodríguez-Pose and Ezcurra, 2011).

- Secondly, Jaliu and Radulescu (2013), Kaufmann and Wagner (2005), Cappelen et al., (2003), Novosák et al., (2015), Wildowicz-Giegiel \& Wyszkowski (2015) mention asymmetries in absorption capacity of particular territorial units. Lagging regions are often disadvantaged in this regard because of their low capability to prepare and submit good projects. This could be notably related to some themes, such as business environment (see, e.g., Belás et al., 2014; Belás et al., 2015) and innovations (see, e.g., Hájek, Grebeníček and Novosák, 2011; Kaufmann and Wagner, 2005).

The aforementioned considerations are highly relevant also for SFs and their contribution to the equity and efficiency goals. In this respect, a number of studies dealt with the geographical distribution of SFs. Lolos (2009), Dall'erba and Le Gallo (2008), Esposti and Bussoletti (2008), Beugelsdijk and Eijffinger (2005) evaluated the impact of SFs allocation on regional convergence. Novosák et al., (2015), Crescenzi (2009), Crescenzi, De Fillipis and Pierangeli (2015), Schraff (2014), Lambrinidis, Psycharis and Rovolis (2005), Dellmuth and Stoffel (2012), Hájek et al., (2012), Smékalová et al., (2015) searched for spatial determinants of SFs allocation. The findings of these studies are rather ambivalent with respect to the equity and efficiency goals, depending on the spatial level and time (ex-ante, ex-post) of evaluation. Ex-ante evaluation at the NUTS 2 level points at higher SFs allocation in lagging regions; however, as expected because of the eligibility criteria for inclusion of regions into the convergence objective. Ex-post evaluation at lower spatial levels provides less obvious results. Lolos (2009) speaks about higher SFs allocation in lagging regions in Greece while Morgenroth (2010) claims the opposite for Irish regions. Nevertheless, this research is still scarce because of the lack of spatially disaggregated data (see, e.g., Heald and Short, 2002; Blažek and Macešková, 2010; Morgenroth, 2010; Cabras, 2011).

Mapping of the geographical distribution of SFs has two additional limitations. Firstly, Hájek et al., (2012) showed a different geographical distribution of SFs for two types of evaluation: (1) real SFs allocation and (2) SFs allocation based on beneficiaries' location (see, e.g., Dall'erba and Le Gallo, 2008; Dupont and Martin, 2006 for this problem). Secondly, Heald and Short (2002) note that real SFs allocation is influenced by public procurement contracts. Thus, SFs allocation in one territorial unit may be squeezed out elsewhere in this way (see, e.g., Cabras, 2011; Peck and Cabras, 2011). Cabras (2011), Peck and Cabras (2011) claim that lagging regions are disadvantaged especially in competitive tendering for specialized goods and services due to their low absorption capacity in these thematic areas.

This paper integrates the research design as follows. Firstly, geographical distribution of SFs is mapped, considering projects realized by regional and local authorities. The importance of regional and local authorities for both, regional and local development and public procuring is respected in this approach. The equity and efficiency goals are analyzed for the both types of evaluation: (1) real SFs allocation and (2) SFs allocation based on beneficiaries' location. Secondly, geographical distribution of public procurement contracts, contracted by regional and local authorities and supported by SFs is mapped. Spatial spillovers from and to lagging regions are quantified in this way. 


\section{METHODOLOGY}

To solve the problem of the lack of spatially disaggregated data, the methodology of this paper was based on particular projects and public procurement contracts. Two databases were, therefore, compiled. The first database contained projects realized by regional and local authorities and supported by SFs in the programming period 2007-2013 (excluding the European territorial cooperation goal). The Regional Information Service of the Center for Regional Development of the Czech Republic (hereafter referred to as RIS CRD) was the source of data. The state in January 2013 was evaluated. The second database contained public procurement contracts contracted by regional and local authorities and supported by SFs which were listed in the Czech official Information System of Public Contracts (hereafter referred to as IS PC) in January 2013. Furthermore, several attributes of projects and public procurement contracts were added into the databases (see table 1). These included also two spatial attributes for defining lagging regions (see table 1 for their description):

- Firstly, the definition of the so called regions with concentrated state support (hereafter referred to as RCSS) was used. Lagging regions were, therefore, understood in accord with Czech regional policy.

- Secondly, the importance of regional hierarchy was emphasized for defining lagging regions. These are understood as peripheral areas of the Czech Republic.

Table 1

Attributes of projects and public procurement contracts

\begin{tabular}{|c|c|c|}
\hline Attributes & Description and information source & Values \\
\hline $\begin{array}{l}\text { Regional } \\
\text { policy }\end{array}$ & $\begin{array}{l}\text { - Projects categorized according to the place of their } \\
\text { realization or beneficiaries' location } \\
\text { - Public procurement contracts categorized according to } \\
\text { beneficiaries' location } \\
\text { - The list of lagging regions defined using the official } \\
\text { Government resolutions at the level of the admin- } \\
\text { istrative districts of municipalities with extended } \\
\text { competence } \\
\text { - RIS CRD for projects; IS PC for public procurement } \\
\text { contracts }\end{array}$ & $\begin{array}{l}\text { 1. Lagging regions } \\
\text { - Structurally affected regions } \\
\text { - Economically weak regions } \\
\text { - Regions with high unemployment } \\
\text { 2. Non-lagging regions } \\
\text { 3. Prague }\end{array}$ \\
\hline $\begin{array}{l}\text { Regional } \\
\text { hierarchy }\end{array}$ & $\begin{array}{l}\text { - Projects categorized according to the place of their } \\
\text { realization or beneficiaries' location } \\
\text { - Public procurement contracts categorized according to } \\
\text { beneficiaries' location } \\
\text { - The levels of regional hierarchy defined as quartiles } \\
\text { of population density at the level of the administrative } \\
\text { districts of municipalities with extended competence } \\
\text { - RIS CRD for projects; IS PC for public procurement } \\
\text { contracts }\end{array}$ & $\begin{array}{l}\text { 1. The highest level of regional hierarchy } \\
\text { 2. High level of regional hierarchy } \\
\text { 3. Low level of regional hierarchy } \\
\text { 4. The lowest level of regional hierarchy } \\
\text { 5. Prague }\end{array}$ \\
\hline $\begin{array}{l}\text { SFs } \\
\text { allocation }\end{array}$ & $\begin{array}{l}\text { - SFs allocation per project/public procurement contract } \\
\text { and place of realization/ beneficiary's location } \\
\text { - RIS CRD for projects; IS PC for public procurement } \\
\text { contracts }\end{array}$ & SFs allocation in CZK \\
\hline
\end{tabular}

Note: In a number of cases, more places of project realization were given in the RIS CRD. However, the information about SFs allocation was at the project level only. Therefore, SFs allocation was distributed between the places as follows. If the beneficiary's location was different from all the places of project realization SFs allocation was distributed evenly between these places. If the beneficiary's location was the same as any place of project realization four times higher SFs allocation was assigned to this place.

Source: own compilation. 
The compiled databases were evaluated in two steps. Firstly, geographical distribution of SFs was visualized on maps at the level of the administrative districts of municipalities with extended competence. Note that SFs allocation was normalized per one inhabitant to control for different population size of particular territorial units. The first insight into the position of lagging regions was provided in this way. Subsequently, standard methods of descriptive and inferential statistics were used. Notably, SFs allocation per one inhabitant was calculated for the categories of the two spatial attributes - regional policy and regional hierarchy. The aggregate SFs allocation refers to the SFs allocation per one inhabitant of the whole category. The average SFs allocation refers to the mean value of the administrative districts of municipalities with extended competence belonging to the same category. In addition, the parametric t-test for two independent samples and one-way ANOVA for more than two independent samples were used to test the hypothesis that the means of the categories, excluding Prague, of the two spatial attributes are not significantly different. The traditional assumptions of the two-sample independent t-test and one-way ANOVA - approximately normally distributed dependent variable for each category and homogeneity of variances - were checked by KolmogorovSmirnoff and Levene's tests respectively. The results did not indicate a violation of these assumptions.

Geographical distribution of public procurement contracts supported by SFs was evaluated in the second step of the methodology. In this respect, a new variable - spatial closeness of public procurement contracts - was defined as the share of public procurement contracts that were contracted to a contractor from the same territorial unit (contractor's headquarter) as the procurer (regional and local authorities). Subsequently, spatial closeness of public procurement contracts was evaluated using the same methodological approach as in the first step of the evaluation - cartographic visualisation and standard methods of descriptive (aggregate and average values of spatial closeness of public procurement contracts) and inferential (two-sample independent t-test and one-way ANOVA) statistics. Once again, the traditional assumptions of the two-sample independent t-test and one-way ANOVA were verified.

\section{EMPIRICAL RESULTS - GEOGRAPHICAL DISTRIBUTION OF SFS}

The evaluation of SFs allocation was based on 15,634 projects realized by regional and local authorities. The total SFs allocation for these projects was CZK 152.2 billion. Figure 1 provides the first insight into the position of lagging regions:

The factor of regional policy does not indicate higher SFs allocation in lagging regions for the both types of evaluation: (1) real SFs allocation and (2) SFs allocation based on beneficiaries' location. Thus, lagging regions are categorized in different classes of SFs allocation. In other words, some lagging regions received very high SFs allocation while other lagging regions very low SFs allocation.

The factor of regional hierarchy seems to be relevant for explaining the SFs allocation on the basis of beneficiaries' location. Thus, administrative districts of large and densely populated Czech cities received a relatively higher SFs allocation. Note that a number of regional and local authorities have their headquarters just in these cities. The importance of regional hierarchy decreases in the evaluation of the real SFs allocation.

The relatively weak position of the capital city of Prague in the both types of evaluation is noteworthy. Hájek et al., (2012) provided a different conclusion when evaluating SFs allocation for all types of recipients. Consequently, regional and local authorities are crucial to weaken the position of the capital city of Prague in SFs allocation. 

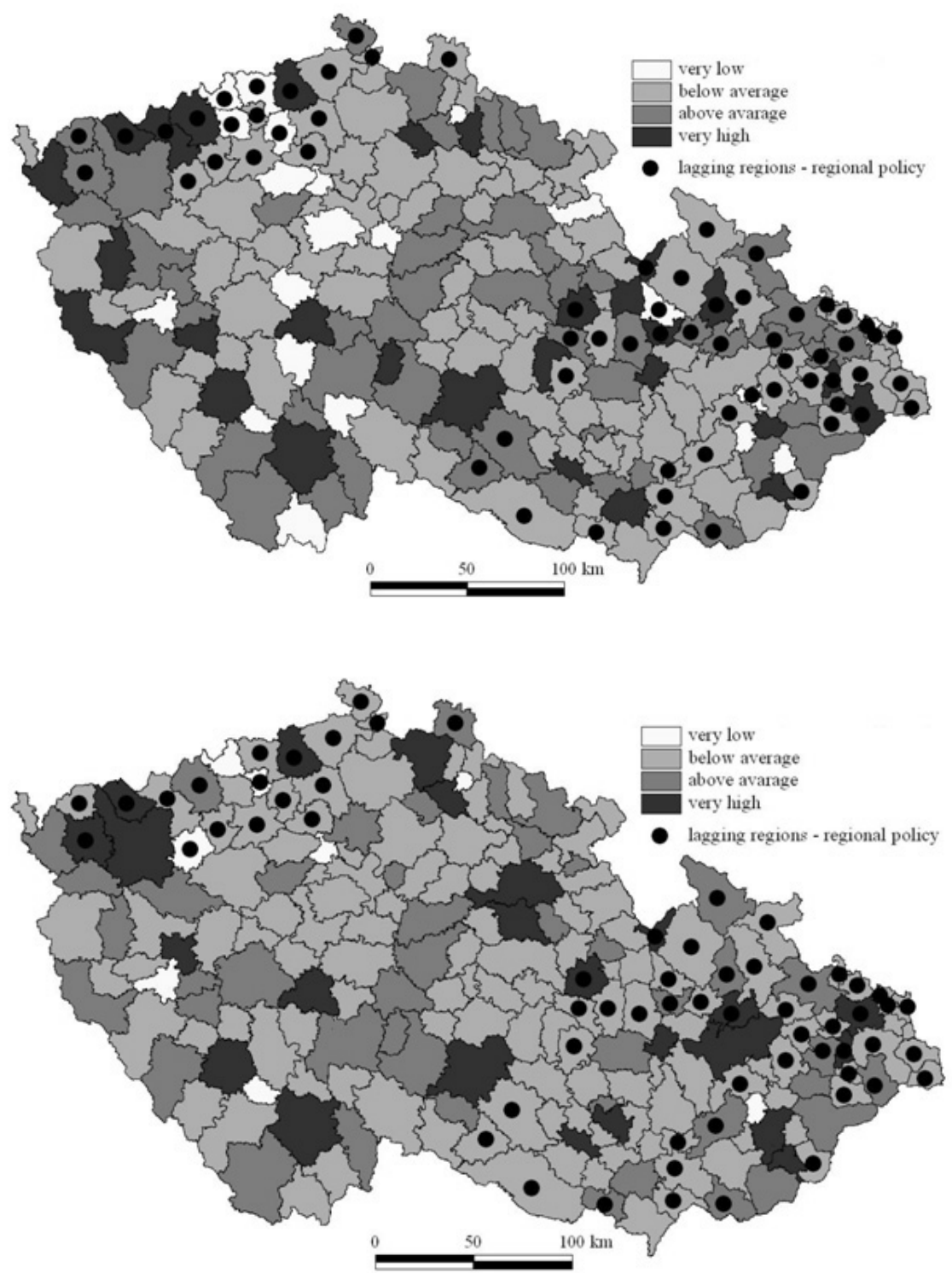

Note: The break classes of the colour-scale calculated at the points of arithmetic mean less standard deviation, arithmetic mean, and arithmetic mean plus standard deviation

Figure 1. Geographical distribution of SFs - SFs allocation per one inhabitant, administrative districts of municipalities with extended competence; real SFs allocation - the map above, SFs allocation based on beneficiaries' location (headquarters) - the map below

Source: own compilation based on the data from the RIS CRD and Czech Statistical Office. 
Tables 2 and 3 confirm and extend the relevance of these findings. Firstly, aggregate SFs allocation per one inhabitant is slightly lower in lagging regions understood as RCSS for the both types of evaluation. Secondly, real SFs allocation indicates even geographical distribution of SFs for the categories of the both variables - regional policy and regional hierarchy. Thirdly, the evaluation based on beneficiaries' location indicates low SFs allocation in economically weak regions and high SFs allocation in densely populated regions. Overall, the results do not support the assumption of higher SFs allocation in lagging regions because of (1) low coherence between the spatial focus of EU Cohesion Policy and Czech regional policy (see, e.g., Hájek et al., 2014); (2) low absorption capacity of lagging regions (see, e.g., Jaliu and Radulescu, 2013); and (3) higher concentration of regional and municipal authorities in densely populated regions. Thus, the strategy of "pouring sugar over cake" seems to be relevant for the evaluation. However, such a strategy does not prefer SFs allocation in lagging regions to SFs allocation in non-lagging regions.

Table 2

Geographical distribution of SFs - regional policy

\begin{tabular}{|c|c|c|c|c|}
\hline \multirow{3}{*}{ Regional policy - categories } & \multicolumn{4}{|c|}{ SFs allocation per one inhabitant (CZK) } \\
\hline & \multicolumn{2}{|c|}{ Real allocation } & \multicolumn{2}{|c|}{ Beneficiaries' location } \\
\hline & Aggregate & Average & Aggregate & Average \\
\hline Lagging regions & 15,198 & 15,987 & 13,858 & 12,316 \\
\hline - Structurally affected regions & 14,816 & 14,560 & 14,873 & 11,190 \\
\hline - Economically weak regions & 14,939 & 15,625 & 9,965 & 9,829 \\
\hline - Regions with high unemployment & 16,464 & 16,041 & 18,366 & 13,888 \\
\hline Non-lagging regions & 16,345 & 15,382 & 16,326 & 11,320 \\
\hline Prague & 4,119 & 4,119 & 7,746 & 7.746 \\
\hline
\end{tabular}

Source: own compilation based on the data from the RIS CRD and Czech Statistical Office

Table 3

Geographical distribution of SFs - regional hierarchy

\begin{tabular}{|c|c|c|c|c|}
\hline \multirow{3}{*}{ Regional hierarchy - categories } & \multicolumn{4}{|c|}{ SFs allocation per one inhabitant (CZK) } \\
\hline & \multicolumn{2}{|c|}{ Real allocation } & \multicolumn{2}{|c|}{ Beneficiaries' location } \\
\hline & Aggregate & Average & Aggregate & Average \\
\hline The highest level & 15,600 & 14,168 & 19,468 & 14,058 \\
\hline High level & 16,066 & 15,170 & 13,963 & 11,941 \\
\hline Low level & 16,414 & 17,035 & 11,541 & 11,119 \\
\hline The lowest level & 16,119 & 16,732 & 10,657 & 10,809 \\
\hline Prague & 4,119 & 4,119 & 7,746 & 7,746 \\
\hline
\end{tabular}

Source: own compilation based on the data from the RIS CRD and Czech Statistical Office.

The aforementioned findings indicate balanced SFs allocation between lagging and non-lagging regions. Question remains whether the differences in the mean values of SFs allocation for the defined categories of regional policy and regional hierarchy, excluding the capital city of Prague, are statistically sig- 
nificant. This question was tested using suitable tests for continuous dependent variable. After checking for their traditional assumptions (approximately normally distributed dependent variable for each category and homogeneity of variances), the parametric t-test for two independent samples and one-way ANOVA were applied. Table 4 reports the results as significance values (p-values) indicating that the differences in the mean values of SFs allocation are not statistically significant for either of the variables, regional policy and regional hierarchy. Thus, also statistical tests do not support the assumption of higher SFs allocation in lagging regions. These results have also several implications. Firstly, the impact of SFs allocation on the equity goal of Czech regional policy is unclear. Secondly, territorially based instruments may increase the coherence between SFs allocation and Czech regional policy. Thirdly, territorial impact assessment (TIA) is highly desirable in order to recognize the spatial impact of SFs allocation.

Table 4

Significance values (p-values) - tests of the hypotheses that the means of SFs allocation for the defined categories are not significantly different (regional policy, regional hierarchy)

\begin{tabular}{|l|c|c|}
\hline \multirow{2}{*}{\multicolumn{1}{|c|}{ Attributes }} & \multicolumn{2}{|c|}{ Significance value } \\
\cline { 2 - 3 } & Real allocation & Beneficiaries' location \\
\hline Regional policy - two categories & 0.596 & 0.387 \\
\hline Regional policy - four categories & 0.875 & 0.289 \\
\hline Regional hierarchy & 0.198 & 0.144 \\
\hline
\end{tabular}

Note: The parametric t-test for two independent samples and Levene's test for equality of variances for the first case; the one-way ANOVA and Levene's test for equality of variances for the remaining two cases

Note: Excluding the category "Prague"

Source: own compilation based on the data from the RIS CRD and Czech Statistical Office.

\section{EMPIRICAL RESULTS - SPATIAL CLOSENESS OF PUBLIC PROCUREMENT CONTRACTS}

The main results from the preceding section indicate no evidence of higher SFs allocation for projects realized by regional and local authorities in lagging regions. Moreover, geographical distribution of SFs allocation for these projects may be further modified by public procurement contracts. This section addresses this issue by analyzing 10,602 public procurement contracts which were contracted by regional and local authorities and supported by SFs. The spatial closeness of public procurement contracts is evaluated.

The first step of the evaluation maps spatial closeness of public procurement contracts at the level of the administrative districts of municipalities with extended competence (see figure 2). In this regard, the factor of regional policy does not appear to be of high relevance for explaining differentiation of the spatial closeness variable because both, lagging and non-lagging regions are categorized in different classes of the variable. Furthermore, high values of the spatial closeness variable for several territorial units at the highest level of regional hierarchy may be observed. However, several territorial units at the lowest level of regional hierarchy indicate high values of the spatial closeness variables as well. Altogether, the geographical pattern of the spatial closeness variable is rather blurred. Tables 5 and 6 extend the findings by providing the main results from the applied methods of descriptive and inferential statistics: 


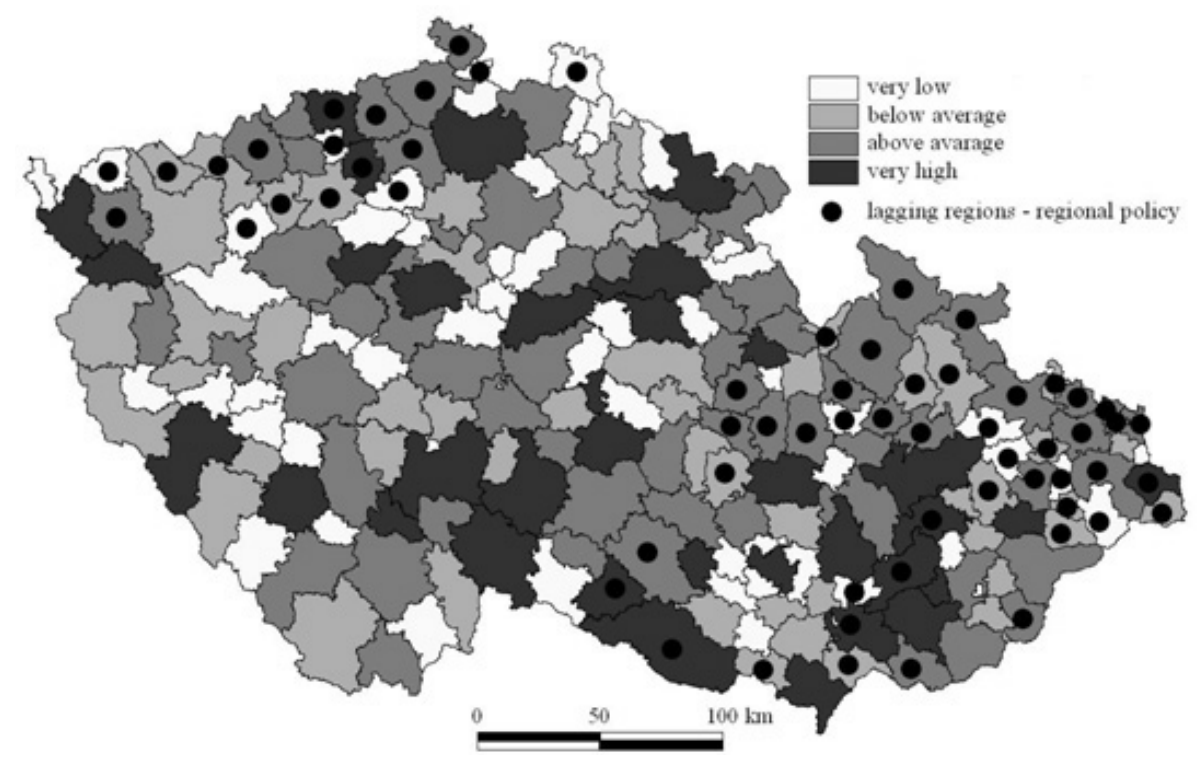

Note: The break classes of the colour-scale calculated at the points of arithmetic mean less standard deviation, arithmetic mean, and arithmetic mean plus standard deviation

Figure 2. Spatial closeness of public procurement contracts (\%) - administrative districts of municipalities with extended competence $(\mathrm{N}=10,602)$

Source: own compilation based on the data from the IS PC.

Spatial closeness of public procurement contracts is higher in non-lagging regions compared with lagging regions. SFs allocation through public procurement contracts is, therefore, more frequently squeezed out from lagging than from non-lagging regions. However, the average values of the spatial closeness variable indicate more complex picture (compare with figure 2).

Spatial closeness of public procurement contracts is relatively high in regions at the highest level of regional hierarchy. Moreover, this gradient is observed also for average spatial closeness. However, the differences are rather modest and statistically not significant (see table 6).

Table 5

Spatial closeness - regional policy and regional hierarchy

\begin{tabular}{|l|c|c|c|c|c|}
\hline \multirow{2}{*}{\begin{tabular}{c}
\multirow{2}{*}{$\begin{array}{c}\text { Categories } \\
\text { Regional policy }\end{array}$} \\
\cline { 6 - 6 }
\end{tabular}} & \multicolumn{2}{|c|}{ Spatial closeness } & \multirow{2}{*}{$\begin{array}{c}\text { Categories } \\
\text { Regional hierarchy }\end{array}$} & \multicolumn{2}{c|}{ Spatial closeness } \\
\cline { 6 - 6 } & Aggregate & Average & & Aggregate & Average \\
\hline Lagging regions & $53.1 \%$ & $17.5 \%$ & The highest level & $55.7 \%$ & $18.6 \%$ \\
\hline - Structurally affected regions & $47.1 \%$ & $14.8 \%$ & High level & $29.5 \%$ & $16.8 \%$ \\
\hline - Economically weak regions & $37.0 \%$ & $19.6 \%$ & Low level & $27.8 \%$ & $15.3 \%$ \\
\hline - Regions with high unemployment & $36.0 \%$ & $17.4 \%$ & The lowest level & $28.7 \%$ & $14.4 \%$ \\
\hline Non-lagging regions & $64.9 \%$ & $15.7 \%$ & Prague & $42.8 \%$ & $42.8 \%$ \\
\hline
\end{tabular}

Source: own compilation based on the data from the IS PC. 
Significance values (p-values) - tests of the hypotheses that the means of the spatial closeness variables for the defined categories of territorial units are not significantly different

(regional policy, regional hierarchy)

\begin{tabular}{|c|c|c|c|}
\hline Attributes & $\begin{array}{c}\text { Regional policy } \\
\text { two categories }\end{array}$ & $\begin{array}{c}\text { Regional policy } \\
\text { four categories }\end{array}$ & Regional hierarchy \\
\hline Significance value & 0.376 & 0.516 & 0.437 \\
\hline
\end{tabular}

Note: The parametric t-test for two independent samples and Levene's test for equality of variances for the first case; the one-way ANOVA and Levene's test for equality of variances for the remaining two cases

Source: own compilation based on the data from the IS PC.

Spatial flows of public procurement contracts between the particular categories of the two spatial attributes - regional policy and regional hierarchy - are shown in tables 7 and 8 . The weak position of lagging regions and regions at the lowest level of regional hierarchy is noteworthy. Thus, high shares of public procurement contracts are squeezed out from these two types of regions and, simultaneously, low shares of public procurement contracts flow into these two types of regions. Note even weaker position of lagging regions and regions at the lowest level of regional hierarchy for the financial evaluation. Altogether, the weak position of lagging regions is caused by their low capability to absorb some types of public procurement contracts and by their disadvantaged position in competition with other applicants from core regions.

Table 7

Spatial flows of public procurement contracts from and to the defined categories of territorial units - regional policy

\begin{tabular}{|l|c|c|c|c|c|c|}
\hline \multirow{2}{*}{$\begin{array}{c}\text { From/to } \\
\text { Regional Policy }\end{array}$} & \multicolumn{3}{|c|}{$\begin{array}{c}\text { Share in the number } \\
\text { of public procurement contracts }\end{array}$} & \multicolumn{3}{c|}{$\begin{array}{c}\text { Share in financial allocation } \\
\text { for public procurement contracts }\end{array}$} \\
\cline { 2 - 7 } & $\begin{array}{c}\text { Lagging } \\
\text { regions }\end{array}$ & $\begin{array}{c}\text { Non-lagging } \\
\text { regions }\end{array}$ & Prague & $\begin{array}{c}\text { Lagging } \\
\text { regions }\end{array}$ & $\begin{array}{c}\text { Non-lagging } \\
\text { regions }\end{array}$ & Prague \\
\hline Lagging regions & $53.1 \%$ & $26.5 \%$ & $20.5 \%$ & $46.5 \%$ & $23.0 \%$ & $30.5 \%$ \\
\hline Non-lagging regions & $9.9 \%$ & $64.9 \%$ & $25.2 \%$ & $6.0 \%$ & $62.2 \%$ & $31.8 \%$ \\
\hline Prague & $2.6 \%$ & $54.7 \%$ & $42.8 \%$ & $1.4 \%$ & $26.5 \%$ & $72.2 \%$ \\
\hline
\end{tabular}

Source: own compilation based on the data from the IS PC.

Table 8

Spatial flows of public procurement contracts from and to the defined categories of territorial units regional hierarchy

\begin{tabular}{|c|c|c|c|c|c|c|c|c|c|c|}
\hline \multirow{2}{*}{$\begin{array}{c}\text { From/to } \\
\text { Regional } \\
\text { hierarchy }\end{array}$} & \multicolumn{4}{|c|}{$\begin{array}{c}\text { Share in the number } \\
\text { of public procurement contracts }\end{array}$} & \multicolumn{5}{c|}{$\begin{array}{c}\text { Share in financial allocation } \\
\text { for public procurement contracts }\end{array}$} \\
\cline { 2 - 13 } & I & II & III & IV & V & I & II & III & IV & V \\
\hline 1 & 2 & 3 & 4 & 5 & 6 & 7 & 8 & 9 & 10 & 11 \\
\hline I & $55.7 \%$ & $8.2 \%$ & $6.2 \%$ & $5.1 \%$ & $24.7 \%$ & $51.7 \%$ & $4.7 \%$ & $10.1 \%$ & $2.0 \%$ & $31.5 \%$ \\
\hline II & $32.8 \%$ & $29.5 \%$ & $10.0 \%$ & $3.8 \%$ & $23.9 \%$ & $32.3 \%$ & $25.0 \%$ & $6.6 \%$ & $1.8 \%$ & $34.3 \%$ \\
\hline
\end{tabular}




\begin{tabular}{|c|c|c|c|c|c|c|c|c|c|c|}
\hline 1 & 2 & 3 & 4 & 5 & 6 & 7 & 8 & 9 & 10 & 11 \\
\hline III & $27.9 \%$ & $14.1 \%$ & $27.8 \%$ & $7.8 \%$ & $22.4 \%$ & $29.7 \%$ & $10.5 \%$ & $23.8 \%$ & $5.1 \%$ & $30.8 \%$ \\
\hline IV & $30.0 \%$ & $10.1 \%$ & $11.4 \%$ & $28.7 \%$ & $19.8 \%$ & $26.5 \%$ & $10.3 \%$ & $12.9 \%$ & $25.9 \%$ & $24.3 \%$ \\
\hline V & $28.8 \%$ & $20.3 \%$ & $6.5 \%$ & $1.6 \%$ & $42.8 \%$ & $17.5 \%$ & $7.0 \%$ & $1.8 \%$ & $1.6 \%$ & $72.2 \%$ \\
\hline
\end{tabular}

Note: I - the highest level of regional hierarchy, II - high level of regional hierarchy, III - low level of regional hierarchy, IV - the lowest level of regional hierarchy, V - Prague

Source: own compilation based on the data from the IS PC.

The main findings from the both empirical sections do not support the assumption of higher SFs allocation in lagging regions. Thus, lagging regions did not receive a higher SFs allocation for projects realized by regional and local authorities. Moreover, lagging regions are more prone to lose higher share of SFs allocation through public procurement contracts. Consequently, these findings ought to be considered in thinking about the relationship between SFs allocation and Czech regional policy.

\section{CONCLUSIONS}

This paper dealt with the SFs allocation for projects realized by Czech regional and local authorities in the programming period 2007-2013. Geographical distribution of SFs in the context of the equity and efficiency goals was mapped. A special attention was paid to the position of lagging regions. The research consisted of two parts. Firstly, geographical distribution of SFs was evaluated. Secondly, spatial spillovers of SFs allocation through public procurement contracts were analyzed. In this way, this paper provides extended knowledge about SFs allocation than other studies (see, e.g., Lolos, 2009; Blažek and Macešková, 2010; Crescenzi, 2009).

The main assumption of this paper was that lagging regions received higher SFs allocation due to the goals of Czech regional policy. However, the main findings of this paper did not support this assumption. Small and statistically insignificant differences were observed between lagging and non-lagging regions. In addition, lagging regions were further disadvantaged by the spatial allocation of public procurement contracts. Thus, high share of these contracts was squeezed out from lagging regions. Inflow of public procurement contracts did not compensate for the outflow. Generally, low coherence between the spatial focus of EU Cohesion Policy and Czech regional policy (see, e.g., Hájek et al.,, 2014; Hudson, 2007) and low absorption capacity of lagging regions (see, e.g., Jaliu and Radulescu, 2013) may be regarded as important determinants of the results.

Several political implications may be formulated from the study. Firstly, more nuanced use of territorially based instruments may increase the coherence between SFs allocation and the equity goal of Czech regional policy. Secondly, the methodology of this paper may be of relevance for Territorial Impact Assessment (TIA) methodologies (see, e.g., Camagni, 2009; Blažek and Macešková, 2010). Thirdly, the thinking about the spatial impact of SFs allocation ought to consider various methodological issues (e.g., type of evaluation, spatial spillovers from public procurement contracts and others). Finally, limitations of the research should be considered as well. These include: (1) the focus of the paper on regional and local authorities only; (2) missing thematic decomposition of SFs allocation; (3) limited research on determinants of SFs allocation; (4) missing discussion of the most suitable spatial level for evaluation. These limitations may be regarded also as the future directions of research. 


\section{ACKNOWLEDGEMENT}

The authors are thankful to the grant No. 16-22141S provided by the Czech Science Foundation for financial support to carry out this research and for grant No. IGA/FaME/2016/010 which provided financial support for this research. Data provision from the Czech Statistical Office (the Zlin Office) is kindly acknowledged.

\section{REFERENCES}

Afonso, A., Furceri, D. (2010), Government size, composition, volatility and economic growth, European Journal of Political Economy, Vol. 26, No. 4, pp. 517-532.

Auteri, M., Costantini, M. (2004), Fiscal policy and economic growth, the case of the Italian regions, The Review of Regional Studies, Vol. 34, No. 1, pp. 72-94.

Barro, R.J., Sala-i-Martin, X. (1992), Public finance in models of economic growth, Review of Economic Studies, Vol. 59, No. 4, pp. 645-661.

Belás, J., Bartoš, P., Habánik, J., Novák, P. (2014), Significant attributes of the business environment in small and mediumsized enterprises, Economics \& Sociology, Vol. 7, No. 3, pp. 22-39.

Belás, J., Bilan, Y., Demjan, V., Sipko, J. (2015), Entrepreneurship in SME segment: case study from the Czech Republic and Slovakia, Amfiteatru Economic, Vol. 17, No. 38, pp. 308-326.

Beugelsdijk, M., Eijffinger, S.C.W. (2005), The effectiveness of structural policy in the European Union, an empirical analysis for the EU-15 in 1995-2001, Journal of Common Market Studies, Vol. 43, No. 1, pp. 37-51.

Blažek, J., Macešková, M. (2010), Regional analysis of public capital expenditure. To which regions is public capital expenditure channelled - to 'rich' or to 'poor' ones? Regional Studies, Vol. 44, No. 6, pp. 679-696.

Boldrin, M., Canova, F. (2001), Inequality and convergence in Europe's regions, reconsidering European regional policies, Economic Policy, Vol. 16, No. 32, pp. 207-253.

Cabras, I. (2011), Mapping the spatial patterns of public procurement. a case study from a peripheral local authority in Northern England, International Journal of Public Sector Management, Vol. 24, No. 3, pp. 187-205.

Camagni, R. (2009), Territorial Impact Assessment for European regions, a methodological proposal and an application to EU Transport Policy, Evaluation and Program Planning, Vol. 32, No. 4, pp. 342-350.

Cappelen, A., Castellaci, F., Fagerberg, J., Verspagen, B. (2003), The impact of EU regional support on growth and convergence in the European Union, Journal of Common Market Studies, Vol. 41, No. 4, pp. 621-644.

Crescenzi, R. (2009), Undermining the principle of concentration? European Union regional policy and the socio-economic disadvantage of European regions, Regional Studies, Vol. 43, No. 1, pp. 111-133.

Crescenzi, R., De Fillipis, F., Pierangeli, F. (2015), In tandem for cohesion? Synergies and conflicts between regional and agricultural policies of the European Union, Regional Studies, Vol. 49, No. 4, pp. 681-704.

Dall'erba, S., Le Gallo, J. (2008), Regional convergence and the impact of European structural funds over 1989-1999, a spatial econometric analysis, Papers in Regional Science, Vol. 87, No. 2, pp. 219-245.

Davoodi, H., Zou, H. (1998), Fiscal decentralization and economic growth, a cross-country study, Journal of Urban Economics, Vol. 43, No. 2, pp. 244-257.

Dellmuth, L.M., Stoffel, M.F. (2012), Distributive politics and intergovernmental transfers: the local allocation of European Union structural funds, European Union Politics, Vol. 13, No. 3, pp. 413-433.

Dupont, V., Martin, P. (2006), Subsidies to poor regions and inequalities, some unpleasant arithmetic, Journal of Economic Geography, Vol. 6, No. 2, pp. 223-240.

Esposti, R., Bussoletti, S. (2008), Impact of Objective 1 funds on regional growth convergence in the European Union, a panel-data approach, Regional Studies, Vol. 42, No. 2, pp. 159-173.

Golobic, M., Marot, N. (2011), Territorial Impact Assessment, integrating territorial aspects in sectoral policies, Evaluation and Program Planning, Vol. 34, No. 3, pp. 163-173. 
Hájek, O., Grebeníček, P., Novosák, J. (2011), Regional innovation strategies in the Czech Republic, Journal of Competitiveness, Vol. 3, No. 2, pp. 11-19.

Hájek, O., Novosák, J., Zahradník, P., Bednář, P. (2012), Regionálni disparity a financováni regionálni politiky - Některé poznatky z České republiky [Regional disparities and financing of regional policy-some lessons from the Czech Republic], Politická ekonomie, Vol. 60, No. 3, pp. 330-348.

Hájek, O., Smékalová, L., Novosák, J., Zahradník, P. (2014), Prostorová koherence národni a evropské regionálni politiky: poznatky z České republiky a Slovenska [Spatial coherence of national and European regional policy: lessons from the Czech Republic and Slovakia], Politická ekonomie, Vol. 62, No 5, pp. 630-644.

Heald, D., Short, J. (2002), The regional dimension of public expenditure in England, Regional Studies, Vol. 36, No. 7, pp. 743-755.

Heidenreich, M., Wunder, C. (2008), Patterns of regional inequality in the enlarged Europe, European Sociological Review, Vol. 24, No. 1, pp. 19-36.

Hepp, R., Hagen, von J. (2011), Fiscal federalism in Germany, stabilization and redistribution before and after unification, Publius, The Journal of Federalism, Vol. 42, No. 2, pp. 234-259.

Hudson, R. (2007), Regions and regional uneven development forever? Some reflective comments upon theory and practice, Regional Studies. Vol. 41, No. 9, pp. 1149-1160.

Jaliu, D., Radulescu, C. (2013), Six years in managing structural funds in Romania. Lessons learned, Transylvanian Review of Administrative Science, Vol. 9, No. 38, pp. 79-95.

Jüßen, F. (2006), Interregional risk sharing and fiscal redistribution in unified Germany, Papers in Regional Science, Vol. 85, No. 2, pp. 235-255.

Kaufmann, A., Wagner, P. (2005), EU Regional policy and the stimulation of innovation, the role of the European Regional Development Fund in the Objective 1 Region Burgenland, European Planning Studies, Vol. 13, No. 4, pp. 581-599.

Lambrinidis, M., Psycharis, Y., Rovolis, A. (2005), Regional allocation of public infrastructure investment, the case of Greece, Regional Studies, Vol. 39, No. 9, pp. 1231-1244.

Lolos, S.E.G. (2009), The effect of EU structural funds on regional growth, assessing the evidence from Greece, 1990-2005, Economic Change Restructuring, Vol. 42, No. 3, pp. 211-228.

Morgenroth, E. (2010), Regional dimension of taxes and public expenditure in Ireland, Regional Studies, Vol. 44, No. 6, pp. 777-789.

Novosák, J., Hájek, O., Zahradník, P., Nekolová, J. (2013), On some aspects of territorial competitiveness: smart specialization in the Zlin 2020 Strategy, Journal of Competitiveness, Vol. 5, No. 3, pp. 3-13.

Novosák, J., Hájek, O., Smékalová, L., Nekolová, J., Škarka, M. (2015), Territorial cohesion and the geography of EU Cohesion Policy funding in the Czech Republic, Transformations in Business \& Economics, Vol. 14, No 3C, pp. 42-59.

Peck, F., Cabras, I. (2011), The impact of local authority procurement on local economies, the case of Cumbria, North West England, Public Policy and Administration, Vol. 26, No. 3, pp. 307-331.

Rodríguez-Pose, A., Ezcurra, R. (2011), Is fiscal decentralization harmful for economic growth? Evidence from the OECD countries, Journal of Economic Geography, Vol. 11, No. 4, pp. 619-643.

Schraff, D. (2014), Buying turnout or rewarding loyalists? Electoral mobilization and EU structural funding in the German Länder, European Union Politics, Vol. 15, No. 2, pp. 277-288.

Smékalová, L., Janíček, P., Škarka, M., Kozák, V. (2015), Spatial concentration of the cohesion policy projects in nationally delimitated intervention areas: the case of the Czech Republic and Poland, Economics \& Sociology, Vol. 8, No. 2.

Wokoun, R. (2007), Regionálni a strukturální politika (politika soudržnosti) Evropské unie v programovém období 2007 2013, Urbanismus a územní rozvoj, Vol. 10, No. 1, pp. 3-7.

Wildowicz-Giegiel, A., \& Wyszkowski, A. (2015), Absorption of EU Funds in the Context of Polish Enterprises Competitiveness Measured by Profitability Ratios. Oeconomia Copernicana, 6(1), pp. 113-123. 